\title{
JURNAL PENDIDIKAN EKONOMI, MANAJEMEN DAN KEUANGAN
}

JPEKA Vol. 2 No. 1 Mei 2018

Hal. 19 - 28

\section{Pengaruh Percaya Diri, Kebiasaan Belajar dan Motivasi Belajar Terhadap Hasil Belajar Siswa Pada Mata Pelajaran Ekonomi}

\author{
Deni Adriani \\ Fakultas Ekonomi, Universitas Negeri Medan,deni_adriani@unimed.ac.id
}

\begin{abstract}
Abstrak
Penelitian ini bertujuan untuk menganalisis (1) Pengaruh percaya diri siswa terhadap hasil belajar. (2) Pengaruh kebiasaan belajar terhadap hasil belajar. (3) Pengaruh motivasi belajar terhadap hasil belajar. (4) Pengaruh percaya diri, kebiasaan belajar dan motivasi belajar secara bersama-sama terhadap hasil belajar pada mata pelajaran ekonomi siswa SMA Pembangunan Laboratorium UNP. Jenis penelitian ini adalah penelitian kuantitatif, yang terdiri dari tiga variabel bebas dan satu variabel terikat. Jumlah populasi dalam penelitian ini adalah 556 siswa. Teknik penarikan sampel yang digunakan adalah pengambilan sampel acak bertahap (multistage random sampling) sehingga terpilih 90 orang sampel. Teknik analisis data dilakukan uji hipotesis dengan menggunakan uji $\mathrm{t}$ dan uji $\mathrm{F}$ pada $\alpha 5 \%$. Hasil penelitian menunjukkan bahwa (1) Terdapat pengaruh yang signifikan antara percaya diri siswa terhadap hasil belajar. (2) Terdapat pengaruh yang signifikan antara kebiasaan belajar siswa terhadap hasil belajar. (3) Terdapat pengaruh yang signifikan antara motivasi belajar siswa terhadap hasil belajar. (4) Terdapat pengaruh yang signifikan antara percaya diri, kebiasaan belajar dan motivasi belajar siswa secara bersama-sama terhadap hasil belajar pada mata pelajaran ekonomi siswa SMA Pembangunan Laboratorium UNP.

Kata Kunci: Percaya Diri, Kebiasaan Belajar, Motivasi Belajar, dan Hasil Belajar Ekonomi.
\end{abstract}

\begin{abstract}
This study aims to analyze (1) The influence of students' self-confidence in learning outcomes. (2) The influence of learning habits on learning outcomes. (3) The influence of learning motivation on learning outcomes (4) The influence of self-confidence, learning habits and motivation of learning together on the learning outcomes in economic subjects of high school students UNP Development Laboratory. This type of research is quantitative research, which consists of three independent variables and one dependent variable. The total population in this study is 556 students. The sampling technique used was the gradual sampling of multistage random sampling so that 90 samples were selected. Data analysis technique is hypothesis test by using $t$ test and $F$ test at $\alpha 5 \%$. The results showed that (1) There is a significant influence between students' self-confidence in learning outcomes. (2) There is a significant influence between the students' learning habits toward the learning outcomes. (3) There is a significant influence between students' learning motivation on learning outcomes. (4) There is a significant influence between self-confidence, learning habits and student learning motivation jointly to the learning outcomes on economic subjects of high school students UNP Development Laboratory.

Keywords: Self-Confidence, Study Habits, Learning Motivation, Economic Learning Outcomes.
\end{abstract}




\section{PENDAHULUAN}

Pendidikan merupakan suatu hal yang sangat penting dan tidak dapat dipisahkan dari kehidupan seseorang baik dalam keluarga, masyarakat, dan bangsa. Negara Indonesia sebagai negara berkembang membutuhkan sumber daya manusia yang berkulitas. Salah satu usaha menciptakan sumber daya manusia yang berkualitas adalah melalui pendidikan. Sekolah sebagai salah satu lembaga pendidikan formal memiliki peranan yang sangat penting dalam mewujudkan tujuan pendidikan nasional melalui proses belajar mengajar.

Pendidikan nasional tersebut mempunyai fungsi yang harus diperhatikan. Fungsi pendidikan nasional dapat dilihat pada Undang-undang No. 20 Tahun 2003 pasal 3 yang menyatakan bahwa:

"Pendidikan nasional berfungsi mengembangkan kemampuan dan membentuk watak serta peradaban bangsa yang bermanfaat dalam rangka mencerdaskan kehidupan bangsa, bertujuan untuk berkembangnya potensi peserta didik agar menjadi manusia yang beriman dan bertakwa kepada Tuhan Yang Maha Esa, berakhlak mulia, sehat, berilmu, cakap, kreatif, mandiri dan menjadi warga negara yang demokratis dan bertanggung jawab."

Keberhasilan pendidikan akan tercapai oleh suatu bangsa apabila ada usaha untuk meningkatkan mutu pendidikan bangsa itu sendiri. Untuk itu pemerintah mengusahakan mutu pendidikan di Indonesia, terutama pendidikan formal. Peningkatan mutu pendidikan di sekolah berkaitan langsung dengan siswa sebagai anak didik dan guru sebagai pendidik.

Belajar akan menghasilkan perubahan-perubahan dalam diri seseorang. Untuk mengetahui sampai sejauh mana perubahan yang terjadi, perlu adanya penilaian. Begitu juga dengan yang terjadi pada seorang siswa yang mengikuti suatu pendidikan selalu diadakan penilaian dari hasil belajarnya. Melalui hasil penilaian itulah nantinya dapat diketahui sejauh mana keberhasilan siswa dalam pembelajaran.

Berdasarkan hasil observasi ke SMA Pembangunan Laboratorium UNP dan dari wawancara dengan salah seorang guru mata pelajaran ekonomi pada tanggal 19 Januari 2012 diketahui bahwa hasil belajar siswa pada mata pelajaran ekonomi tergolong rendah. Pada dasarnya dalam proses belajar mengajar hal utama yang ingin dicapai adalah pencapaian hasil belajar yang optimal, dengan kata lain sedapat mungkin siswa mampu menguasai materi pelajaran dan konsep-konsep yang diajarkan yang ditandai dengan perolehan nilai tinggi dalam belajar. Berikut ini gambaran awal tentang hasil belajar mata pelajaran ekonomi siswa SMA Pembangunan Laboratorium UNP pada semester ganjil tahun ajaran 2011/2012.

Tabel 1. Nilai UAS Mata Pelajaran Ekonomi Siswa SMA Pembangunan Laboratorium
\begin{tabular}{ccccc}
\multicolumn{4}{c}{ UNP Semester ganjil 2011/2012 } \\
\cline { 2 - 5 } No & Kelas & Nilai & Persentase Siswa & Persentase Siswa \\
& & KKM & Tuntas (\%) & Tidak Tuntas (\%) \\
1. & X.A & 70 & 31,71 & 68,29 \\
2. & X.B & 70 & 29,27 & 70,73 \\
3. & XI IPS 3 & 70 & 33,33 & 66,67 \\
4. & XI IPS 4 & 70 & 40,48 & 59,52 \\
\hline
\end{tabular}

(Sumber data: dokumen guru bidang studi ekonomi tahun 2012)

Hasil belajar mata pelajaran ekonomi siswa di atas menunjukkan bahwa siswa belum mampu mencapai kriteria ketuntasan minimal (KKM) yang dalam hal ini adalah nilai 70. Hal ini dapat dilihat dari tabel di atas dimana dari ke empat kelas menunjukkan persentase siswa yang 
tuntas lebih kecil dibandingkan siswa yang tidak tuntas. Sebenarnya untuk memperoleh hasil belajar yang optimal banyak sekali faktor-faktor yang mempengaruhinya, salah satu faktor tersebut diantaranya kondisi mental siswa pada saat proses belajar mengajar berlangsung.

Masalah cukup serius terjadi jika seseorang merasa terlalu banyak kelemahan dan tidak memiliki kelebihan sama sekali. Kelemahan-kelemahan pribadi memiliki aspek yang sangat luas dan berkaitan dengan kehidupan di masa lalu. Rasa tidak percaya diri akan menghambat seseorang dalam mencapai berbagai tujuan dalam hidupnya. Hal ini akan mengakibatkan seseorang mengalami perasaan stagnasi atau kemacetan yang mengakibatkan rendahnya kepercayaan diri (Hakim, 2002).

Dari hasil observasi pada tanggal 19 Januari 2012 terhadap 41 orang siswa yang sedang mengikuti pelajaran ekonomi terlihat bahwa masih banyak siswa yang tidak berani dalam menyampaikan ide maupun pendapat mereka pada saat berlangsungnya proses belajar mengajar. Hal ini terlihat ketika guru memberikan kesempatan untuk bertanya hanya 2 atau 3 orang siswa saja yang mengajukan pertanyaan.

Selain itu juga terlihat siswa kurang bersemangat dalam mengikuti proses pembelajaran, kurang mandiri, kurang terampil, kurang berorientasi pada kualitas serta minimnya kemampuan dalam memecahkan masalah. Hal ini mengakibatkan proses pembelajaran menjadi kurang menarik.

Selain masalah percaya diri, kebiasaan belajar juga merupakan salah satu faktor yang mepengaruhi proses dan hasil belajar. Kebiasaan belajar yang terarah dan terencana diharapkan dapat menunjang kegiatan belajar agar siswa mampu mencapai tujuan-tujuan belajar yang telah dirumuskan dalam perencanaan pembelajaran.

Djaali (2008:128) menyatakan bahwa kebiasaan belajar diartikan sebagai cara atau teknik yang menetap pada diri siswa pada waktu menerima pelajaran, membuka buku, mengerjakan tugas, dan pengaturan waktu untuk menyelesaikan kegiatan.

Berdasarkan observasi secara sederhana di SMA Pembangunan Laboratorium UNP ditemukan siswa yang sikap dan kebiasaan belajarnya negatif, seperti kebiasaan pada waktu menerima pelajaran yang terkesan acuh tak acuh, tidak mendengarkan dengan sungguh-sungguh penjelasan dari guru, sebagian siswa terlihat acuh ketika guru mencatat poin-poin penting dari materi yang diajarkan. Sebagian siswa juga mengaku bahwa jarang sekali mereka membaca terlebih dahulu materi yang akan disampaikan oleh guru.

Kemudian dari pada itu motivasi belajar juga sangat menentukan keberhasilan pembelajaran. Hal ini seiring dengan pendapat Hardjo dan Badjuri (2012) menyatakan bahwa "Siswa akan belajar dengan sungguh-sungguh tanpa dipaksa, bila memiliki motivasi yang besar; yang dengan demikian diharapkan dapat mencapai prestasi yang tinggi."

Berdasarkan pengamatan awal yang dilakukan oleh peneliti masih ada sebagian siswa yang kurang memiliki motivasi dalam belajar ekonomi. Hal ini bisa dilihat dari sikap siswa dalam belajar yang mengindikasikan bahwa hasrat siswa untuk mencapai keberhasilan dalam belajar masih rendah. Dari 41 orang siswa yang di observasi hanya sebagian kecil yang terlihat sungguhsungguh dalam mendengarkan penjelasan guru. Siswa belum memahami bahwa belajar adalah kebutuhan, sehingga kegiatan belajar seakan-akan bukan merupakan sesuatu yang penting yang harus mereka ikuti dengan sebaik-baiknya

Penelitian ini bertujuan untuk mendeskripsikan: (1) Pengaruh percaya diri siswa terhadap hasil belajar pada mata pelajaran ekonomi siswa SMA Pembangunan Laboratorium UNP. (2) 
Pengaruh kebiasaan belajar terhadap hasil belajar pada mata pelajaran ekonomi siswa SMA Pembangunan Laboratorium UNP. (3) Pengaruh motivasi belajar terhadap hasil belajar pada mata pelajaran ekonomi siswa SMA Pembangunan Laboratorium UNP. (4) Pengaruh percaya diri, kebiasaan belajar dan motivasi belajar terhadap hasil belajar pada mata pelajaran ekonomi siswa SMA Pembangunan Laboratorium UNP.

\section{METODE}

Penelitian ini menggunakan metode kuantitatif yaitu proses menemukan pengetahuan yang menggunakan data berupa angka sebagai alat menemukan keterangan mengenai apa yang ingin diketahui. Jenis penelitian ini menggunakan pendekatan korelasional karena berupaya untuk mengetahui ada tidaknya hubungan antara dua atau beberapa variabel (Arikunto, 2010:247).

Dimana dalam penelitian ini mencari pengaruh variabel percaya diri terhadap hasil belajar, kebiasaan belajar terhadap hasil belajar, motivasi belajar terhadap hasil belajar, dan percaya diri, kebiasaan belajar dan motivasi belajar secara bersama-sama terhadap hasil belajar ekonomi siswa SMA Pembangunan Laboratorium UNP.

Populasi dalam penelitian ini adalah seluruh siswa SMA Pembangunan Laboratorium UNP. Adapun jumlah populasi dalam penelitian ini sebanyak 556 orang. Adapun teknik penarikan sampel yang digunakan adalah pengambilan sampel acak bertahap (multistage random sampling) sehingga diperoleh 90 orang siswa yang terpilih menjadi sampel dalam penelitian ini.

\section{HASIL DAN PEMBAHASAN}

\section{Hasil Estimasi Regresi}

Tabel 2. Estimasi Regresi Berganda Variabel Percaya diri, Kebiasaan Belajar dan Motivasi Belajar

\begin{tabular}{|c|c|c|c|c|c|c|}
\hline \multicolumn{7}{|c|}{ Coefficients $^{\mathrm{a}}$} \\
\hline & & \multirow{2}{*}{\multicolumn{2}{|c|}{ Unstandardized Coefficients }} & \multirow{2}{*}{\multicolumn{2}{|c|}{$\begin{array}{l}\text { Standardized } \\
\text { Coefficients }\end{array}$}} & \multirow[b]{3}{*}{ Sig. } \\
\hline & & & & & & \\
\hline \multicolumn{2}{|c|}{ Model } & B & Std. Error & Beta & $\mathrm{t}$ & \\
\hline \multirow[t]{4}{*}{1} & (Constant) & 11.684 & 6.447 & & 1.812 & .073 \\
\hline & Percaya Diri & .433 & .170 & .288 & 2.556 & .012 \\
\hline & Kebiasaan Belajar & .547 & .208 & .299 & 2.629 & .010 \\
\hline & Motivasi Belajar & .296 & .110 & .253 & 2.692 & .009 \\
\hline
\end{tabular}

a. Dependent Variable: Hasil Belajar

Dari data dalam tabel 2 dapat diperoleh persamaan analisis estimasi regresi berganda sebagai berikut:

$$
\hat{Y}=11.684+0.433 X_{1}+0.547 X_{2}+0.296 X_{3}
$$

Dari persamaan regresi dapat diartikan:

1. Nilai konstanta=11,684 artinya tanpa adanya faktor percaya diri, kebiasaan belajar dan motivasi belajar yang mempengaruhi hasil belajar maka nilai output hasil belajar (Y) adalah 11,684 satuan. 
2. Nilai $b_{1}=0,433$ artinya pengaruh antara percaya diri terhadap hasil belajar positif dengan asumsi faktor lain yang mempengaruhi tetap maka kenaikan percaya diri sebesar satu satuan maka hasil belajar akan meningkat sebesar 0,433 satuan.

3. Nilai $\mathrm{b}_{2}=0,547$ artinya pengaruh antara kebiasaan belajar terhadap hasil belajar positif dengan asumsi faktor lain yang mempengaruhi tetap maka kenaikan kebiasaan belajar sebesar satu satuan maka hasil belajar akan meningkat sebesar 0,547 satuan.

4. Nilai $b_{3}=0,296$ artinya pengaruh antara motivasi belajar terhadap hasil belajar positif dengan asumsi faktor lain yang mempengaruhi tetap maka kenaikan motivasi belajar sebesar satu satuan maka hasil belajar akan meningkat sebesar 0,296 satuan.

\section{Uji Hipotesis}

\section{a. Hipotesis Pertama}

Hipotesis pertama dalam penelitian ini adalah "Terdapat pengaruh yang signifikan antara percaya diri siswa terhadap hasil belajar pada mata pelajaran ekonomi siswa SMA Pembangunan Laboratorium UNP. Untuk mengetahui apakah variabel percaya diri $\left(\mathrm{X}_{1}\right)$ berpengaruh secara signifikant terhadap hasil belajar siswa (Y) maka dilakukan uji t.

Dari tabel 2 di atas terlihat nilai thitung variabel percaya diri siswa $\left(\mathrm{X}_{1}\right)$ sebesar 2,556 sedangkan tabel sebesar 1,988 pada $\alpha 0,05$. Hal ini berarti thitung $>$ tabel. Dengan demikian dapat dikatakan bahwa hipotesis pertama diterima, yang berarti bahwa variabel percaya diri $\left(\mathrm{X}_{1}\right)$ mempunyai pengaruh yang signifikan terhadap hasil belajar siswa (Y) pada mata pelajaran ekonomi siswa SMA Pembangunan Laboratorium UNP.

\section{b. Hipotesis Kedua}

Hipotesis kedua dalam penelitian ini adalah "Terdapat pengaruh yang signifikan antara kebiasaan belajar siswa terhadap hasil belajar pada mata pelajaran ekonomi siswa SMA Pembangunan Laboratorium UNP. Untuk mengetahui apakah variabel kebiasaan belajar $\left(\mathrm{X}_{2}\right)$ berpengaruh secara signifikant terhadap hasil belajar siswa $(\mathrm{Y})$ maka dilakukan uji t.

Dari tabel 2 di atas terlihat nilai thitung variabel kebiasaan belajar $\left(\mathrm{X}_{2}\right)$ sebesar 2,629 sedangkan tabel sebesar 1,988 pada $\alpha 0,05$. Hal ini berarti thitung $>t_{\text {tabel. }}$ Dengan demikian dapat dikatakan bahwa hipotesis kedua diterima, yang berarti bahwa variabel kebiasaan belajar $\left(\mathrm{X}_{2}\right)$ mempunyai pengaruh yang signifikan terhadap hasil belajar siswa (Y) pada mata pelajaran ekonomi siswa SMA Pembangunan Laboratorium UNP.

\section{c. Hipotesis ketiga}

Hipotesis ketiga dalam penelitian ini adalah "Terdapat pengaruh yang signifikan antara motivasi belajar siswa terhadap hasil belajar pada mata pelajaran ekonomi siswa SMA Pembangunan Laboratorium UNP. Untuk mengetahui apakah variabel motivasi belajar $\left(\mathrm{X}_{3}\right)$ berpengaruh secara signifikant terhadap hasil belajar siswa (Y) maka dilakukan uji t.

Dari tabel 2 di atas terlihat nilai thitung variabel motivasi belajar $\left(\mathrm{X}_{3}\right)$ sebesar 2,692 sedangkan tabelsebesar 1,988 pada $\alpha$ 0,05. Hal ini berarti thitung $>t_{\text {tabel. }}$. Dengan demikian dapat dikatakan bahwa hipotesis ketiga diterima, yang berarti bahwa variabel motivasi belajar $\left(\mathrm{X}_{3}\right)$ mempunyai pengaruh yang signifikan terhadap hasil belajar siswa (Y) pada mata pelajaran ekonomi siswa SMA Pembangunan Laboratorium UNP. 


\section{d. Hipotesis keempat}

Hipotesis keempat dalam penelitian ini adalah "Terdapat pengaruh yang signifikan antara percaya diri, kebiasaan belajar dan motivasi belajar siswa secara bersama-sama terhadap hasil belajar pada mata pelajaran ekonomi siswa SMA Pembangunan Laboratorium UNP”.

Untuk mengetahui apakah variabel percaya diri $\left(\mathrm{X}_{1}\right)$, kebiasaan belajar $\left(\mathrm{X}_{2}\right)$ dan motivasi belajar $\left(\mathrm{X}_{3}\right)$ secara bersama-sama berpengaruh signifikan terhadap hasil belajar siswa (Y) maka dilakukan uji F. Untuk lebih jelasnya dapat dilihat dari tabel 3 berikut:

Tabel 3.Hasil Analisis Pengaruh Percaya Diri, Kebiasaan Belajar dan Motivasi Belajar secara bersama-sama terhadap Hasil Belajar Siswa

\begin{tabular}{|c|c|c|c|c|c|c|}
\hline \multicolumn{2}{|c|}{ Model } & \multirow{2}{*}{$\begin{array}{l}\text { Sum of } \\
\text { Squares }\end{array}$} & \multirow{2}{*}{$\frac{\text { Df }}{3}$} & \multirow{2}{*}{$\begin{array}{l}\text { Mean } \\
\text { Square }\end{array}$} & \multirow{2}{*}{$\frac{F}{32.775}$} & \multirow{2}{*}{$\frac{\text { Sig. }}{2.000^{\mathrm{a}}}$} \\
\hline 1 & Regression & & & & & \\
\hline & Residual & 2940.294 & 86 & 34.189 & & \\
\hline & Total & 6301.975 & 89 & & & \\
\hline \multicolumn{7}{|c|}{$\begin{array}{l}\text { a. Predictors: (Constant), Motivasi Belajar, Percaya Diri, Kebiasaan Belajar } \\
\text { b. Dependent Variable: Hasil Belajar }\end{array}$} \\
\hline
\end{tabular}

Dari tabel 3 di atas terlihat nilai Fhitungvariabel percaya diri $\left(\mathrm{X}_{1}\right)$, kebiasaan belajar $\left(\mathrm{X}_{2}\right)$ dan motivasi belajar $\left(\mathrm{X}_{3}\right)$ secara bersama-sama berpengaruh terhadap hasil belajar siswa (Y) sebesar 32,775 sedangkan $F_{\text {tabel }}$ sebesar 2,71 pada df 1 (jumlah variabel-1) = 3, df 2 (n-k-1) atau 90-3-1 $=86$ dan $\alpha$ 0,05 Hal ini berarti $F_{\text {hitung }}>F_{\text {tabel. }}$. Dengan demikian dapat dikatakan bahwa hipotesis keempat diterima, yang berarti bahwa variabel percaya diri $\left(\mathrm{X}_{1}\right)$, kebiasaan belajar $\left(\mathrm{X}_{2}\right)$ dan motivasi belajar $\left(\mathrm{X}_{3}\right)$ secara bersama-sama berpengaruh terhadap hasil belajar siswa $(\mathrm{Y})$ pada mata pelajaran ekonomi siswa SMA Pembangunan Laboratorium UNP.

\section{Pengaruh Percaya Diri terhadap Hasil Belajar}

Berdasarkan hasil pengolahan data melalui analisis regresi diperoleh bahwa percaya diri siswa berpengaruh positif dan signifikan terhadap hasil belajar ekonomi siswa SMA Pembangunan Laboratorium UNP. Dari hasil pengujian hipotesis dapat dilihat bahwa percaya diri berpengaruh signifikan terhadap hasil belajar, thitung variabel percaya diri siswa $\left(\mathrm{X}_{1}\right)$ sebesar 2,556 sedangkan tabel sebesar 1,988 pada $\alpha=0,05$. Maka hipotesis yang diajukan diterima artinya percaya diri berpengaruh secara signifikan dan positif terhadap hasil belajar ekonomi siswa SMA Pembangunan Laboratorium UNP.

Hasil pengujian hipotesis yang diperoleh tersebut memperlihatkan bahwa siswa yang memiliki percaya diri dalam belajar ditandai dengan keberanian, semangat untuk mencapai sesuatu, berdiri sendiri, terampil, berorientasi pada kualitas dan mempunyai kemampuan dalam memecahkan masalah dalam belajar sehingga dapat menunjang peningkatan hasil belajar siswa.

Hal ini seiring dengan pendapat Hakim (2002:6) menyatakan percaya diri sebagai suatu keyakinan seseorang terhadap segala aspek kelebihan yang dimilikinya dan keyakinan tersebut membuatnya merasa mampu untuk bisa mencapai berbagai tujuan didalam hidupnya. Dalam hal ini dapat dilihat bahwa rasa percaya diri akan menumbuhkan sikap optimisme yang tinggi, dimana seseorang tersebut dengan penuh keyakinan menggunakan segala aspek kelebihan yang 
dimilikinya untuk mencapai berbagai tujuan di dalam hidupnya. Termasuk tujuan-tujuan yang ingin dicapai dalam belajar.

Hal ini sesuai dengan yang diungkapkan oleh Davis (dalam Slameto, 2003:155) menyatakan bahwa percaya diri berupa peningkatan keyakinan siswa bahwa ia mampu memecahkan masalah-masalah yang dihadapi siswa dalam belajar, dan juga merupakan sumber rasa aman dalam diri siswa.

Dengan demikian rasa percaya diri siswa akan menjadi salah satu faktor pendorong meningkatnya hasil belajar siswa. Dalam hal ini siswa yang percaya diri akan lebih berani, bersemangat dalam mencapai sesuatu, berdiri sendiri, terampil, berorientasi pada kualitas serta memiliki kemampuan dalam memecahkan masalah-masalah yang dihadapinya dalam belajar sehingga hasil belajarnya menjadi lebih baik.

\section{Pengaruh Kebiasaan Belajar terhadap Hasil Belajar}

Hasil pengolahan data melalui analisis regresi diperoleh bahwa percaya diri siswa berpengaruh positif dan signifikan terhadap hasil belajar ekonomi siswa SMA Pembangunan Laboratorium UNP. Dari hasil pengujian hipotesis dapat dilihat bahwa kebiasaan belajar berpengaruh signifikan terhadap hasil belajar, dimana terlihat nilai thitung variabel kebiasaan belajar $\left(\mathrm{X}_{2}\right)$ sebesar 2,629 sedangkan ttabel sebesar 1,988 pada $\alpha=0,05$. Hal ini berarti thitung $>t_{\text {tabel. }}$. Dengan demikian dapat dikatakan bahwa hipotesis kedua diterima, yang berarti bahwa variabel kebiasaan belajar $\left(\mathrm{X}_{2}\right)$ mempunyai pengaruh yang signifikan terhadap hasil belajar siswa (Y) pada mata pelajaran ekonomi siswa SMA Pembangunan Laboratorium UNP.

Hasil pengujian hipotesis yang diperoleh tersebut memperlihatkan bahwa kebiasaan belajar siswa pada waktu menerima pelajaran, membuka buku, mengerjakan tugas dan pengaturan waktu belajar dapat menunjang peningkatan hasil belajar siswa.

Siswa yang mempunyai kebiasaan belajar yang baik dilihat dari kebiasaan pada waktu menerima pelajaran. Terwujud dalam bentuk sikap mendengarkan dengan baik saat guru menerangkan pelajaran ekonomi, membuat catatan ekonomi dengan rapi serta mencatat hal-hal penting yang terkait materi yang disampaikan guru.

Hal ini didukung oleh pendapat Slameto (2003) mengatakan kebiasaan belajar siswa akan mempengaruhi prestasi belajarnya tergantung pada kuantitas dan kualitas yang biasa dilakukan oleh siswa di dalam kelas maupun di luar kelas. Hal ini dipertegas oleh Djaali (2008) bahwa hasil belajar mempunyai korelasi positif dengan kebiasaan belajar.

Dengan demikian dapat kita simpulkan bahwa kebiasaan belajar yang baik akan dapat menunjang pencapaian hasil belajar yang baik pula. Dimana dalam hal ini kebiasaan belajar yang baik tidak hanya menyangkut lama waktu yang digunakan untuk belajar, melainkan juga kualitas dari waktu yang digunakan untuk belajar.

\section{Pengaruh Motivasi Belajar terhadap Hasil Belajar}

Berdasarkan hasil pengolahan data melalui analisis regresi diperoleh bahwa motivasi belajar berpengaruh signifikan dan positif terhadap hasil belajar ekonomi siswa SMA Pembangunan Laboratorium UNP. Dari hasil pengujian hipotesis dapat dilihat bahwa motivasi belajar berpengaruh signifikan terhadap hasil belajar, terlihat nilai thitung variabel motivasi belajar $\left(\mathrm{X}_{3}\right)$ sebesar 2,692 sedangkan t tabel sebesar 1,988 $\alpha=0,05$. Hal ini berarti thitung $>t_{\text {tabel. }}$. Dengan demikian dapat dikatakan bahwa hipotesis ketiga diterima, yang berarti bahwa variabel motivasi belajar 
$\left(\mathrm{X}_{3}\right)$ mempunyai pengaruh yang signifikan terhadap hasil belajar siswa (Y) pada mata pelajaran ekonomi siswa SMA Pembangunan Laboratorium UNP.

Hasil pengujian hipotesis yang diperoleh tersebut memperlihatkan bahwa siswa yang mempunyai motivasi dalam belajar ditandai dengan hasrat ingin berhasil, adanya kebutuhan dalam belajar, adanya harapan dan cita-cita masa depan, adanya penghargaan dalam belajar, adanya kegiatan yang menarik dalam belajar serta adanya lingkungan belajar yang kondusif sehingga dapat menunjang peningkatan hasil belajar siswa.

Hal di atas sesuai dengan pendapat Brophy (dalam Glynn etc: 2011) yang menyebutkan: "Motivation to learn is "a student tendency to find academic activities meaningful and worthwhile and to try to derive the intended academic benefits from them". Hal ini memberi gambaran bahwa motivasi belajar merupakan kecenderungan siswa untuk menemukan kegiatan akademik yang berarti berharga dan mencoba untukmemperoleh manfaat akademis dari kegiatan belajar tersebut.

Hal ini sesuai dengan pendapat Sardiman (2001) motivasi belajar merupakan faktor psikis di luar kemampuan intelektual, dimana motivasi berperan dalam menumbuhkan gairah, semangat dan merasa senang dalam belajar. Seorang siswa yang memiliki motivasi yang tinggi juga akan memiliki semangat yang kuat untuk melakukan kegiatan belajar. Begitu pula sebaliknya seorang siswa yang tidak memiliki motivasi atau rendahnya motivasi dalam belajar, maka siswa tersebut sulit sekali meraih keberhasilan dalam belajar. Dengan demikian motivasi belajar berhubungan erat dengan hasil belajar siswa.

\section{Pengaruh Percaya Diri, Kebiasaan Belajar dan Motivasi Belajar terhadap Hasil Belajar Ekonomi Siswa SMA Pembangunan Laboratorium UNP}

Berdasarkan hasil pengolahan data melalui analisis regresi berganda diperoleh bahwa percaya diri, kebiasaan belajar dan motivasi belajar berpengaruh signifikan dan positif terhadap hasil belajar ekonomi siswa SMA Pembangunan Laboratorium UNP. Hasil pengujian hipotesis dapat dilihat bahwa nilai Fhitung variabel percaya diri $\left(\mathrm{X}_{1}\right)$, kebiasaan belajar $\left(\mathrm{X}_{2}\right)$ dan motivasi belajar $\left(\mathrm{X}_{3}\right)$ secara bersama-sama berpengaruh terhadap hasil belajar siswa $(\mathrm{Y})$ sebesar 32,775 sedangkan $F_{\text {tabel }}$ sebesar 2,71 Hal ini berarti $F_{h i t u n g}>F_{\text {tabel. }}$ Dengan demikian dapat dikatakan bahwa hipotesis keempat diterima, yang berarti bahwa variabel percaya diri $\left(\mathrm{X}_{1}\right)$, kebiasaan belajar $\left(\mathrm{X}_{2}\right)$ dan motivasi belajar $\left(\mathrm{X}_{3}\right)$ secara bersama-sama berpengaruh terhadap hasil belajar siswa (Y) pada mata pelajaran ekonomi siswa SMA Pembangunan Laboratorium UNP.

Hasil yang diperoleh sesuai dengan teori faktor-faktor yang dapat mempengaruhi hasil belajar dapat ditinjau dari dua hal yaitu faktor yang berasal dari dalam diri siswa (internal) dan faktor yang berasal dari luar diri siswa (eksternal). Menurut Aunurrahman (2009:178) ada beberapa faktor internal yang yang mempengaruhi hasil belajar siswa yaitu: ciri khas/karakteristik siswa, sikap terhadap belajar, motivasi belajar, konsentrasi belajar, mengolah bahan belajar, menggali hasil belajar, rasa percaya diri dan kebiasaan belajar.

Lebih lanjut Aunurrahman (2009:184) menjelaskan bahwa rasa percaya diri merupakan salah satu kondisi psikologis seseorang yang berpengaruh terhadap aktivitas fisik dan mental dalam proses pembelajaran. Rasa percaya diri pada umumnya muncul ketika seseorang melakukan atau terlibat di dalam suatu aktivitas tertentu dimana pikirannya terarah untuk untuk mencapai suatu hasil yang diinginkannya.

Selain percaya diri, kebiasaan belajar juga merupakan faktor yang mempengaruhi hasil 
belajar. Hal ini berarti melalui kebiasaan belajar yang baik akan memungkinkan bagi siswa untuk memperoleh hasil belajar yang baik pula. Kemudian dari pada itu motivasi belajar juga merupakan faktor yang berpengaruh positif dan signifikan terhadap hasil belajar siswa. Hal ini sejalan dengan pendapat Sardiman (2011) yang menyatakan bahwa hasil belajar akan menjadi optimal, kalau ada motivasi. Makin tepat motivasi yang diberikan, maka makin berhasil pula pelajaran itu. Jadi motivasi akan senantiasa menentukan intensitas usaha belajar bagi para siswa.

Dari hasil uji hipotesis yang dilakukan menunjukkan bahwa variabel percaya diri, kebiasaan belajar dan motivasi belajar secara parsial maupun secara bersama-sama berpengaruh signifikan terhadap hasil belajar. Hal ini berarti bahwa hasil penelitian ini dapat digeneralisasikan untuk keseluruhan populasi di SMA Pembangunan Laboratorium UNP.

\section{Ucapan Terima Kasih}

Artikel ini ditulis dari tesis penulis di Pascasarjana Universitas Negeri Padang untuk itu ucapan terima kasih kepada yang terhormat tim penguji Prof. Dr. Bustari Muchtar, Dr. Sri Ulfa Sentosa,MS., Prof.Dr. I Made Arnawa, M.Si, Prof.Dr.Azwar Ananda,M.A., Dr.Idris,M.Si.

\section{PENUTUP}

\section{Simpulan}

Berdasarkan pembahasan yang telah dilakukan sebelumnya maka dapat diambil kesimpulan sebagai berikut:

1. Berdasarkan pengujian hipotesis pertama diketahui bahwa terdapat pengaruh yang signifikan antara percaya diri siswa terhadap hasil belajar pada mata pelajaran ekonomi siswa SMA Pembangunan Laboratorium UNP. Nilai thitung variabel percaya diri siswa $\left(\mathrm{X}_{1}\right)$ sebesar 2,556 sedangkan tabel sebesar 1,988 Hal ini berarti thitung $>t_{\text {tabel. Dengan }}$ demikian dapat dikatakan bahwa hipotesis pertama diterima, yang berarti bahwa variabel percaya diri $\left(\mathrm{X}_{1}\right)$ mempunyai pengaruh yang signifikan terhadap hasil belajar siswa (Y) pada mata pelajaran ekonomi siswa SMA Pembangunan Laboratorium UNP.

2. Berdasarkan pengujian hipotesis kedua diketahui bahwa terdapat pengaruh yang signifikan antara kebiasaan belajar siswa terhadap hasil belajar pada mata pelajaran ekonomi siswa SMA Pembangunan Laboratorium UNP. Nilai thitung variabel kebiasaan belajar $\left(\mathrm{X}_{2}\right)$ sebesar 2,629 sedangkan tabel sebesar 1,988 Hal ini berarti thitung $>t_{\text {tabel. }}$. Dengan demikian dapat dikatakan bahwa hipotesis kedua diterima, yang berarti bahwa variabel kebiasaan belajar $\left(\mathrm{X}_{2}\right)$ mempunyai pengaruh yang signifikan terhadap hasil belajar siswa (Y) pada mata pelajaran ekonomi siswa SMA Pembangunan Laboratorium UNP.

3. Hasil pengujian hipotesis ketiga diketahui bahwa terdapat pengaruh yang signifikan antara motivasi belajar siswa terhadap hasil belajar pada mata pelajaran ekonomi siswa SMA Pembangunan Laboratorium UNP. Nilai thitung variabel motivasi belajar $\left(\mathrm{X}_{3}\right)$ sebesar 2,692 sedangkan tabel sebesar 1,988 Hal ini berarti $t_{\text {hitung }}>t_{\text {tabel. }}$. Dengan demikian dapat dikatakan bahwa hipotesis ketiga diterima, yang berarti bahwa variabel motivasi belajar $\left(\mathrm{X}_{3}\right)$ mempunyai pengaruh yang signifikan terhadap hasil belajar siswa (Y) pada mata pelajaran ekonomi siswa SMA Pembangunan Laboratorium UNP.

4. Berdasarkan pengujian hipotesis keempat diketahui bahwa terdapat pengaruh yang signifikan antara percaya diri, kebiasaan belajar dan motivasi belajar siswa secara 
bersama-sama terhadap hasil belajar pada mata pelajaran ekonomi siswa SMA

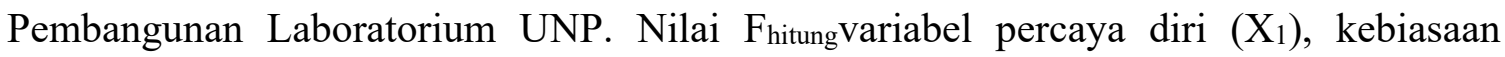
belajar $\left(\mathrm{X}_{2}\right)$ dan motivasi belajar $\left(\mathrm{X}_{3}\right)$ secara bersama-sama terhadap hasil belajar siswa (Y) sebesar 32,775 sedangkan $F_{\text {tabel }}$ sebesar 2,71. Hal ini berarti $F_{\text {hitung }}>F_{\text {tabel }}$ dengan demikian dapat dikatakan bahwa hipotesis keempat diterima, yang berarti bahwa variabel percaya diri $\left(\mathrm{X}_{1}\right)$, kebiasaan belajar $\left(\mathrm{X}_{2}\right)$ dan motivasi belajar $\left(\mathrm{X}_{3}\right)$ secara bersama-sama berpengaruh terhadap hasil belajar siswa $(Y)$ pada mata pelajaran ekonomi siswa SMA Pembangunan Laboratorium UNP.

\section{Saran}

Berdasarkan hasil penelitian di atas maka disarankan:

1. Bagi siswa agar lebih meningkatkan rasa percaya diri dalam belajar, merubah kebiasaan belajar kearah yang positif serta meningkatkan motivasi belajar agar hasil belajar menjadi lebih baik.

2. Bagi guru agar dapat memotivasi siswa agar lebih percaya diri, menerapkan kebiasaan belajar yang baik dan memotivasi siswa dalam mengikuti proses belajar agar hasil belajar yang diperoleh siswa menjadi lebih baik.

3. Bagi orang tua agar lebih memperhatikan kebutuhan anak dalam belajar dengan memperhatikan perkembangan fisik dan psikis anak sehingga anak lebih percaya diri, mempunyai kebiasaan belajar yang baik dan mempunyai motivasi yang tinggi dalam belajar.

4. Peneliti selanjutnya hendaknya dapat melakukan penelitian lebih lanjut untuk dapat melihat faktor-faktor lain yang memberikan pengaruh terhadap hasil belajar siswa selain penelitian yang telah peneliti lakukan.

\section{DAFTAR PUSTAKA}

Arikunto. 2010. Manajemen Penelitian. Jakarta: Rineka Cipta.

Aunurrahman. 2009. Belajar dan Pembelajaran. Bandung: Alfabeta

Djaali. 2008. Psikologi Pendidikan. Jakarta: Bumi Aksara.

Glynn, Shawn M., Etc. 20122. Motivation to Learn in General Education Programs. (Online). (jesserbishop.wiki.westga.edu/file/view/motivation+general+education.pdf/. $\quad$ diakses 7 Desember 2012)

Hakim, Thursan. 2002. Mengatasi Rasa Tidak Percaya Diri. Jakarta. Puspa Swara.

Hardjo, sri dan Badjuri.2012. Pengaruh Motivasi Berprestasi dan Cara Belajar Terhadap Prestasi Belajar Siswa Sekolah Dasar di Kabupaten Semarang. Jurnal.Http://www.lppm.ut.ac.id/htmppublikasi/12srihardjo.htm. diakses tgl 29 Mei 2012.

Sardiman. 2011. Interaksi dan Motivasi Belajar Mengajar. Jakarta. PT. Raja Grafindo Persada.

Slameto. 2003. Belajar dan Faktor-Faktor yang Mempengaruhinya. Jakarta. Rineka Cipta. 